\title{
UNION SCHISM IN PERSPECTIVE: FLEXIBLE DOCTRINES, DOUBLE STANDARDS, AND PROJECTED ANSWERS
}

\author{
Clyde W. Summers*
}

7 HE dramatic ouster of the Teamsters, Bakery Workers, and other corrupt unions from the AFL-CIO, for all its historic significance, created no substantial legal problem. The tie that binds an international union to the federation is but a flimsy thread easily severed, even by such an unceremonious act as John L. Lewis' curt telegram to William Green, "We disaffiliate." International unions such as the United Mine Workers and the International Association of Machinists have moved fitfully in and out of federations, but their legal right to sever the affiliation ties has never been challenged. ${ }^{1}$ Ousting of internationals by the federation, although done less casually and with more ritual, has produced little litigation. In 1907 the AFL expelled the Brewery Workers, ${ }^{2}$ and in 1926 expelled the Railway Clerks, ${ }^{3}$ both for alleged failure to comply with jurisdictional awards. In 1937 the AFL ousted nine internationals for alleged dual unionism and refusal to follow federation policies. ${ }^{4}$ These unions became the core of the CIO, which in 1949 and 1950 ousted eleven internationals for claimed adherence to communist purposes rather than the objectives and principles of the CIO. ${ }^{5}$ All of these ousters generated but one reported case, and it upheld the federation's right to expel. ${ }^{6}$

*Professor of Law, Yale University. Member, New York Bar. B.S., 1939, J.D., 1942, University of Illinois; LL.M., 1946, S.J.D., 1952, Columbia University.

1. The United Mine Workers left the AFL in 1935 to help form the CIO, left the CIO in 1942, joined the AFL again in 1946, and finally left the AFL again in 1947. See Smith, Labor Law, Cases and Materials 23, 41 (1950). The International Association of Machinists left the AFL in 1943, rejoined later the same year, left again in 1945, and finally rejoined in 1951. See News Developments in Labor Relations, 27 L.R.R.M. 23 (1951). The Carpenters withdraw from the AFL in 1953 and then rejoined later the same year. See News Developments in Labor Relations, 32 L.R.R.M. 33 (1953). They now threaten to withdraw again if action is taken against them under the Ethical Practices Code. See N.Y. Times, Nov. 15, 1958, p. 23.

2. See Jaffe, Inter-Union Disputes in Search of a Forum, 49 Yale L.J. 424, 439 (1940).

3. $I d$. at 433-34 n.36. Both of these unions were finally reinstated, but the Brewery Workers were again expelled in 1941.

4. See Goldberg, AFL-CIO, Labor United 42 (1956).

5. Id. at 181-83.

6. See Tisa v. Potofsky, 90 F. Supp. 175 (S.D.N.Y. 1950). 
Schism creates serious legal problems only when local unions attempt to secede from their parent international. Expulsion of the Bakery and Confectionery Workers has led to litigation only because the AFL-CIO chartered a rival international to recapture dissatisfied locals. In contrast, the Teamsters have had no schism cases because locals have not attempted to break out. Severance of affiliation with the federation is but an event which may or may not trigger a secession movement by local unions. The legal problems, however, center in the relationship between the seceding local and its abandoned parent. Regardless of the source of dissatisfaction which drives the local to secede, whether it is communism, corruption, or simple incompetence, the main problems are the same. Who shall get the local union's assets? Who shall act as bargaining representative? What shall be the status of the current collective contract?

\section{Flexible Doctrines for Judicial Control}

In secession cases the courts have been concerned almost exclusively with the question of who shall get the assets of the seceding local. The core of articulate judicial doctrine is that courts should not prescribe the rules to govern internal union disputes, but rather should enforce the union's own rules as set forth in its organic law-the union constitution. The contract theory is but a metaphor for the basic premise of judicial restraint in interfering with union self-government. The courts, however, have manipulated this theory to inject their own rules and values.

If the union constitution happens not to be explicit the court may use the gap as an opening for judicial control. For example, in Brown v. Hook ${ }^{7}$ a local of the Machinists had called a strike in the shipyards in wartime. When threatened with discipline by the international, it seceded. The constitution provided that upon "expulsion, lapsing or disbanding of any local" the assets should go to the international. The court found this clause broad enough to cover secession and ordered forfeiture of the local's assets. ${ }^{8}$ However, in Vilella $v$. $M c G r a t b^{9}$ locals of the left wing Mine Mill and Smelter Workers which

7. 79 Cal. App. 2d 781, 180 P.2d 982 (1947).

8. For a direct contrast, see Local 13013, District 50, UMW v. Cikra, 86 Ohio App. 41, 90 N.E.2d 154 (1949) where the court held that provisions covering disbanding or dissolving the local union did not apply because it had not disbanded but transferred.

9. 136 Conn. 645,74 A.2d 187 (1950). 
seceded because of claimed fraud in the election of international officers were allowed to keep the assets. The court found in the local charters an implied right to withdraw, and ruled, in the absence of any explicit provision, that a majority vote was sufficient.

However gaps or ambiguities in the constitution can be readily cured by amendment, and union officials are not lax or impotent in protecting the international against local insurrections. ${ }^{10}$ Thus, within six months after the locals in the Vilella case seceded, the Mine Mill and Smelter Workers Union amended its constitution to curb future secessions. ${ }^{11}$ Out of such experiences, most unions have now evolved nearly foolproof provisions prohibiting seceding groups from taking the local's assets. $^{12}$ The $\mathrm{BCW}$ is no exception. ${ }^{13}$ If the courts restricted themselves to enforcing the union's own organic law, the outcome would almost always be reasonably clear-the seceding local would lose its assets.

The courts, however, have not been content with this limited role of enforcing the constitution, but have sought devices to escape its binding words. The New Jersey court in International Union of United Brewery Workers, CIO v. Becherer ${ }^{14}$ attempted to make the right to

10. For an excellent discussion of the typical clauses in union constitutions through which the international seeks to keep the local union under control and make itself supreme, see Cohn, The International and the Local Union, N.Y.U. 11TH ANN. Conf. ON LABOR 7 (1958).

11. International Union of Mine Mill and Smelter Workers Const. art. 25, $\S \S 1$-4. This constitution was adopted by the Forty-Third Convention, August, 1947.

12. Courts can at times find gaps invisible to the normal legal eye. In Suffridge v. O'Grady, 84 N.Y.S.2d 211 (Sup. Ct. 1948) a local of the Retail Clerks seceded. The constitution provided that funds of a seceding local should be held by the international for the clerks in that locality until they reorganized. The court held that as the constitution did not require that they reorganize as a local of the international, the seceding group was entitled to the money because it now represented the reorganized clerks.

13. BCW Const. art. XIV, $\$ 8$ (1956-61) provides:

All funds and property of the local union shall be held by it in the name of the local union to be used only for the purpose of effectuating the objectives of this Constitution and in accordance with its provisions. Should a local union dissolve, secede, or have its charter revoked all its money and property shall revert to the ownership of the International Union, and the International Secretary-Treasurer may authorize, in writing, a member of a nearby local or a representative to take charge of and turn same over to the International Union .... If the defunct local is reorganized within one year then the funds and property taken over by the International Union shall become the funds and property of the reorganized local.

14. 4 N.J. Super. 456, 67 A.2d 900 (1949). 
the assets depend on whether the local was an independent entity or a subservient unit. Looking to the entire parent-local relationship has a first impression appeal. ${ }^{15}$ However, it ultimately leads the courts deep into the thicket of union structures. Furthermore, it provides no intelligible guide as to how independent a local union must be, and in what respects, to be entitled to walk out with assets in hand. ${ }^{16} \mathrm{Al}$ though this full-view approach is flexible enough to justify awarding the assets to the seceding local, it suffers the serious handicap of dangling in full view the very words the court needs to forget. It was quickly abandoned in New Jersey ${ }^{17}$ and has been used by other courts only as filler in the goulash of reasons used to excuse overriding the constitutional provisions. ${ }^{18}$

Less subtle but more effective is the Clark $v$. Fitzgerald ${ }^{19}$ device of using contract doctrines to dissolve the contract and free the seceding local. Continued affiliation with the CIO is declared to be an "implied condition" of the contract between the international and its locals. Severance of that tie "substantially frustrates the objects contemplated" by the parent and the local. Thus, the judicial alchemy of bold assertion transforms the flimsy thread between the federation and the international into a golden lifeline between the international and the local. Other implied conditions can be as easily created. In one BCW case the court declared that failure of the international to remove corrupt officers justified the local in treating its contract with the international at an end. ${ }^{20}$ Continuing along the line toward plausibility

15. See Isaacson, The Local and the International, N.Y.U. $5 \mathrm{TH}$ ANN. Conf. on LABOr 413, 429 (1952). See also Note, The Legal Consequences of Labor Union Schism, 63 Harv. L. Rev. 1413, 1417 (1950).

16. In United Pub. Workers v. Pratt, 25 L.R.R.M. 2246 (N.J. Super. Ct. 1949), one New Jersey judge held that a local of the union was independent under the Becherer doctrine, but in United Pub. Workers v. Fenimore, 6 N.J. Super. 589, 70 A.2d 901 (1950) another New Jersey judge held that a different local of the same union did not come within the Becherer doctrine.

Although the formal structure of the union may appear highly centralized, the effective power may in fact be in the local union. See Cohn, supra note 10, at 20-22. But for a contrary view which considers locals inherently subservient, see Rose, $R e$ lationship of the Local Union to the International Organization, 38 VA. L. Rev. 843, 863 (1952).

17. See Harker v. McKissock, 7 N.J. 323, 81 A.2d 480 (1951).

18. See, e.g., Local 1140, UE v. UE, 232 Minn. 217, 45 N.W.2d 408 (1950); Duris v. Iozzi, 6 N.J. Super. 530, 70 A.2d 793 (1949); Local 13013, District 50, UMW v. Cikra, 86 Ohio App. 41, 90 N.E.2d 154 (1949).

19. 197 Misc. 355, 93 N.Y.S.2d 768 (Sup. Ct. 1949).

20. Crawford v. Newman, 175 N.Y.S.2d 903 (Sup. Ct. 1958). 
the court might find implied conditions not to rig international conventions, not to impose oppressive receiverships, or not to neglect the local unions. Breach of any of these would enable the local to secede and take its assets, regardless of the provisions in the union constitution. Thus, by creating implied conditions the courts can escape the binding terms of the union's organic law and substitute their own rules of union government.

Obviously the judicial doctrines do not dictate decisions, but they give the courts a range of freedom to pursue their own purposes. The cloak of contract language conceals the extent to which this freedom is used and to what ends. However, a simple historical view of the cases provides suggestive clues. Prior to 1949, the courts rather consistently denied the right of seceding groups to take the local assets. ${ }^{21}$ When Sidney Hillman split off from the United Garment Workers in 1916 to form the Amalgamated Clothing Workers, the seceding locals lost their assets; ${ }^{22}$ and when dissatisfied locals of the United Mine Workers seceded to form the Progressive Mine Workers in 1934, they likewise forfeited their assets. ${ }^{23}$ Cases arising out of the AFL expulsion of CIO unions followed the same pattern. West coast locals of the Carpenters (AFL) which seceded to form the Woodworkers (CIO) attempted to save their funds by paying expenses in advance and then voting to dissolve and distribute the assets to the members. All of their efforts failed, ${ }^{24}$ as did equally ingenious devices and arguments

21. See, e.g., Brown v. Hook, 79 Cal. App. 2d 781, 180 P.2d 982 (1947); Wolchok v. Durst, 66 N.Y.S.2d 295 (Sup. Ct. 1946); Bacon v. Paradise, 318 Mass. 649, 63 N.E.2d 571 (1945); Hogan v. Williams, 55 N.Y.S.2d 904 (Sup. Ct. 1945); Alexion v. Hollingsworth, 289 N.Y. 91, 43 N.E.2d 825 (1942); Textile Workers Union v. Federal Labor Union, 240 Ala. 239, 198 So. 606 (1940); Steinmiller v. McKeon, 21 N.Y.S.2d 621 (Sup. Ct. 1940), aff'd, 288 N.Y. 508, 41 N.E.2d 925 (1942); O'Neill v. Delaney, 158 N.Y.S. 665 (Sup. Ct. 1909). But see Moyer v. Butte Miners Union, 232 Fed. 788 (D. Mont. 1916), aff'd, 246 Fed. 657, cert. denied, 245 U.S. 671 (1917).

22. See Brownfield v. Simon, 94 Misc. 720,158 N.Y.S. 187 (Sup. Ct. 1916), aff'd, 225 N.Y. 643, 121 N.E. 858 (1919); cf. Schweitzer v. Schneider, 86 N.J. Eq. 256, 98 Atl. 1086 (1916).

23. See Low v. Harris, 90 F.2d 783 (7th Cir. 1937).

24. E.g., Harris ex rel. Carpenters Union v. Backman, 160 Ore. 520, 86 P.2d 456 (1939); Local 2508, Lumber Workers v. Cairns, 197 Wash. 476, 85 P.2d 1109 (1938); Lumber Workers v. International Woodworkers, 197 Wash. 491, 85 P.2d 1099 (1938); Local 2618, Plywood Workers v. Taylor, 197 Wash. 515, 85 P.2d 1116 (1938). For related cases in which the closed shop contract with the Carpenters Union was enforced against the seceding Woodworkers and the discharges upheld, see $M \& M$ Wood Working Co. v. Plywood Workers, 23 F. Supp. 11 (D. Ore. 1938); M \& M Wood Working Co. v. NLRB, 101 F.2d 938 (9th Cir. 1939). 
used by other local unions which sought to secede from AFL internationals to join the $\mathrm{CIO}^{25}$ However, when a local of the Brewery Workers (CIO) sought to move to the AFL, the Becherer doctrine was devised to enable the seceding local to take its assets. ${ }^{26}$

In 1949 the CIO expulsion of left wing internationals ushered in a new series of cases. In all of these, the local unions were trying to secede from the left wing international. In over half (11 out of 19) of the reported cases deciding who was entitled to the local union's assets, the seceding group won. ${ }^{27}$ Constitutional provisions were warped or ignored, ${ }^{28}$ local unions were declared independent entities under the Becherer doctrine, ${ }^{29}$ and the "implied condition" of affiliation was

25. In Liggett v. Koivunen, 227 Minn. 114, 34 N.W.2d 345 (1948), the majority group, in planning secession, amended the bylaws of the Sick Relief and Burial Benefit Associations to make it a separate entity and make the benefits payable to the member of any union. The court nullified this device and awarded the whole $\$ 20,000$ benefit fund to the forty-five remaining in the old local. In Quinn v. Marvin, 168 Ore. 52, 120 P.2d 227 (1941), the officers who went with the seceding group claimed they were entitled to hold the assets, as they were still officers of the old AFL local until removed after trial. The court, however, held that upon joining the CIO they automatically forfeited their office and ordered them to turn the assets over to the officers elected by the remnant. See also Marvin v. Manash, 175 Ore. 311, 153 P.2d 251 (1944); State v. Kelly Postal, 215 Minn. 427, 10 N.W.2d 373 (1943); Walker v. International Longshoremen's Ass'n, 1-A L.R.R.M. 564 (Cal. Super. Ct. 1938).

26. See International Union of United Brewery Workers v. Becherer, 4 N.J. Super. 456, 67 A.2d 900 (1949); cf. Textile Workers Union v. Federal Labor Union, 240 Ala. 239, 198 So. 606 (1940).

27. E.g., Vilella v. McGrath, 136 Conn. 645, 74 A.2d 187 (1950); Fitzgerald v. Riverside Labor Hall, Inc. 27 L.R.R.M. 2366 (N.Y. Sup. Ct. 1951); UE v. Kraft, 25 L.R.R.M. 2174 (Ohio C.P. 1949); cases cited at notes 28-30 infra.

Litigation also involved questions of who was entitled to check-off payments from the employer, General Elec. Co. v. Emspak, 94 F. Supp. 601 (S.D.N.Y. 1950); Chase Brass \& Copper Workers Union v. Chase Brass \& Copper Co., 136 Conn. 660, 74 A.2d 194 (1950), and the right to use the number of the local union, Fitzgerald v. Dillon, 92 F. Supp. 681 (E.D.N.Y. 1950); UE v. Drenzyk, 25 L.R.R.M. 2267 (Conn. Super. Ct. 1950). A large number of cases brought in the federal courts were dismissed for lack of jurisdiction. Establishing diversity was nearly impossible. See, e.g., Seslar v. Local 901, 186 F.2d 403 (7th Cir. 1951); Fitzgerald v. Santoianni, 95 F. Supp. 438 (D. Conn. 1950). Suits brought under section 301 of the Taft-Hartley Act were also rejected. See Kriss v. White, 87 F. Supp. 734 (N.D.N.Y. 1949); Snoots v. Vejlupek, 87 F. Supp. 503 (N.D. Ohio 1949).

28. See, e.g., Ford v. Houchins, 25 L.R.R.M. 2191 (Pa. C.P. 1949), where the court said general provisions of the local constitution for majority rule take precedence over the specific secession provisions of the international constitution. For an incredible interpretation of an anti-injunction statute as protecting the local's right to the assets, see UAW v. Wells Mfg. Corp., 28 L.R.R.M. 2656 (Wis. Cir. Ct. 1951).

29. See, e.g., United Pub. Workers v. Pratt, 25 L.R.R.M. 2246 (N.J. Super. Ct. 1949); Huntsman v. McGovern, 91 N.E.2d 717 (Ohio C.P. 1949). 
created by judicial sleight of hand. ${ }^{30}$ Duing this same period, cases involving other internationals followed the traditional pattern, with seceding locals regularly losing their assets. ${ }^{31}$

The reason for this startling shift and feverish search for rationalizations was tactlessly revealed by one blunt judge who declared: "So the $\mathrm{UE}$ comes before this court, in equity, garbed in red as the CIO saw it and so accused it, and tries to awaken the court's conscience to claimed wrongs perpetrated against it." 32 Therefore the plaintiff had not come into court with "clean hands" and was entitled to no relief.

Not all courts, however, tailored their legal doctrines to fit the moral or political mould of the parties, for nearly half of the cases enforced the restrictive provisions of the union constitution and barred those breaking out of the left wing unions from taking with them the local assets. ${ }^{33}$ Thus, in Fitzgerald $v$. Abramson ${ }^{34}$ the court refused to distort the reasonably clear provisions of the $\mathrm{UE}$ constitution, rejected the existence of an implied condition and then declared: "Behind this dispute may lurk ideological differences of great consequence. The dispute itself, however, relates strictly to property rights, and, of course, this Court is not authorized in resolving such a dispute, to ap-

30. See Clark v. Fitzgerald, 197 Misc. 355, 93 N.Y.S.2d 768 (Sup. Ct. 1949); Local 1140, UE v. UE, 232 Minn. 217, 45 N.W.2d 408 (1950); Duris v. Iozzi, 6 N.J. Super. 530, 70 A.2d 793 (1949); Bozeman v. Fitzmaurice, 107 N.E.2d 627 (Ohio App. 1951).

31. See Schnitzler v. Scida, 27 L.R.R.M. 2288 (E.D.N.Y. 1951) (Bakery Workers); Overton-Bey v. Jacobs, 131 N.Y.S.2d 31 (Sup. Ct. 1954) (Longshoremen); Feller v. Egelhofer, 125 N.Y.S.2d 816 (Sup. Ct. 1953) (Brewery Workers); Retail Clerks Int'l Ass'n v. Neifeld, 73 Pa. D. \& C. 60 (C.P. 1950) (26 L.R.R.M. 2365). The only exception was Zander v. Laveglia, 34 L.R.R.M. 2455 (N.Y. Sup. Ct. 1954) which involved an independent local which had affiliated only after special negotiations and special agreement as to its continued autonomy. When it disaffiliated, it was awarded the assets.

32. Fitzgerald v. Riverside Labor Hall, Inc., 27 L.R.R.M. 2366, 2367 (N.Y. Sup. Ct. 1951). In Bozeman v. Fitzmaurice, 107 N.E.2d 627, 630 (Ohio App. 1951), the court declared that the courts "may not shut their eyes nor close their ears to matters that are of general public knowledge" and noted that the UE had been expelled for "malevolent acts of communism."

33. See Fitzgerald v. Abramson, 89 F. Supp. 504 (S.D.N.Y. 1950); Seslar v. Local 901, UE, 87 F. Supp. 447 (N.D. Ind. 1949); Bridgeport Brass Workers Local 320 v. Smith, 136 Conn. 654, 74 A.2d 191 (1950); Nadworny v. Emery, 25 L.R.R.M. 2594 (Mass. Super. Ct. 1950); Walter Kidde \& Co. v. UE, 7 N.J. 528, 82 A.2d 184 (1951); United Pub. Workers v. Fennimore, 6 N.J. Super. 589, 70 A.2d 901 (1950); UE v. Kwiecien, 25 L.R.R.M. 2178 (N.Y. Sup. Ct. 1949); Federation of Ins. Workers v. United Office Workers, 74 A.2d 446 (R.I. Sup. Ct. 1950).

34. Supra note 33. 
ply one rule of law for Communists and another for anti-Communists." ${ }^{35}$

With the BCW cases, the last vestiges of judicial restraint have disappeared. Although the BCW constitution explicitly provides that if a local union should secede all of its money and property shall revert to the international, ${ }^{36}$ no seceding local has lost its assets. The constitutional provisions have been vitiated by court-created implied conditions, ${ }^{37}$ but more significantly, even the verbal pretense of following the union's own rules has been abandoned by free use of the "clean hands" doctrine. In Crawford v. Newman, ${ }^{38}$ the first BCW case, this mercurial doctrine was stated: "A flagrant violation, or series of violations, of the basic principles of a trade union by one party renders his hands so unclean that he may not seek the aid of a court of equity in enforcing the letter of his rights under the constitution."

Although most of the cases have found the international's hands dirtied, as one case put it, by "corruption, dishonesty, and favoritism," ${ }^{39}$ uncleanness has also been found in "complete defiance ... to the wishes of those identified with the local," and in "tyrannical" conduct. ${ }^{40}$

The courts have boldly used their self-made freedom to noble endsaiding the labor movement in combatting communism and corruption. However there is little reason to rejoice, for precedents have been established which lead to the most irresponsible form of judicial intervention in internal union affairs. The courts have made the rights of the parties depend on the court's approval of their general pattern of conduct or their observance of "the basic principles of a trade union." The guide is not the union's own organic law, but only the judge's vague notions of trade union morality. ${ }^{41}$ The result is uncontrolled

35. Id. at 512 .

36. Supra note 13.

37. See King v. American Bakery Workers, 41 L.R.R.M. 2617 (Cal. Super. Ct. 1958); Olson v. Carbonara, 41 L.R.R.M. 2637 (Ill. Super. Ct. 1958); Crawford v. Newman, 175 N.Y.S.2d 903 (Sup. Ct. 1958); Alvino v. Carraccio, 2 Lab. ReL. Rep. (43 L.R.R.M.) 2184 (Pa. Ct. C.P. Nov. 26, 1958).

38. 11 Misc. 2d 322, 174 N.Y.S.2d 667 (Sup. Ct.) aff'd sub nom. Crawford v. Ehrlich, 5 App. Div. 2d 859, 174 N.Y.S.2d 881 (1958).

39. Kralstein v. Sorchinski, 41 L.R.R.M. 2528, 2530 (N.J. Super. Ct. 1958).

40. Stott v. Zellmann, 41 L.R.R.M. 2749, 2750 (Ill. Cir. Ct. 1958). In Olson v. Miller, 41 L.R.R.M. 2579 (D.D.C. 1958), the court did not even say what it had found unclean. In all the cases in which the "clean hands" doctrine was used, the court also found a breach of an implied condition.

41. Even if the court uses the logic of implied condition, the standard may be the same. Thus in Crawford v. Newman, 174 N.Y.S.2d 903, 907 (Sup. Ct. 1958), the 
prescription of proper union conduct with judges wielding a stamp of approval.

This danger is aggravated by the courts' inherent difficulty in determining the substantive factual issue-the morality of the parties. The courts will be confronted with charges and counter-charges, each party trying to prove the other unworthy of legal relief. To inquire into these charges would lead the court into a dismal swamp, for in these cases virtue is seldom unalloyed or vice unrelieved. ${ }^{42}$ Of course, if courts are satisfied with reports of congressional committees, newspaper stories, and untested affidavits, their task is simpler, but it scarcely increases our confidence in the reliability of their decisions. Judicial acceptance of the findings of the AFL-CIO Ethical Practices Committee pushes the problem back another step to an inquiry into the reliability of that committee and its procedures.

In addition to the disquieting fears engendered by judicial assertiveness is the vague uneasiness that the tests used by the courts by-pass the real problems posed by union schisms. Neither enforcing the rigid provisions of the union constitution nor stripping rights from those who have committed "flagrant violations . . . of the basic principles of a trade union" come to grips with the unique needs of unions as institutions for collective bargaining.

\section{The Double Standard and the Board's Premises}

In secession cases the National Labor Relations Board is concerned primarily with determining who shall act as the collective bargaining representative. If there is no collective agreement, the matter is simply resolved by an election, for the choice of representatives lies with the employees. Secession poses problems for the Board only if it occurs during the contract term. The Board must then decide whether the existence of the contract should bar the employees from choosing a new representative.

court found it "unconscionable" not to allow petitioner to disaffiliate in the face of the corruption and dishonesty of the union; and in Alvino v. Carraccio, 2 Lab. ReL. ReP. (43 L.R.R.M.) 2184 (Pa. Ct. C.P. Nov. 26, 1958), the court said, "When plaintiff, rather than correcting corruption in its own ranks, desired independence, they gave the defendants carte blanche to disaffiliate."

42. The hostility against President Cross of the BCW was not based solely on his misuse of union funds, but was in part based on his efforts to modernize the union structure and allow rationalization and mechanization of the industry. These efforts helped create an opposition faction in the union, and it was this opposition faction which supported the ouster of the $\mathrm{BCW}$ and became the core of the newly created rival. Fortune, Feb., 1958, p. 211. 
Prior to 1950 the Board had evolved two exceptions to its contract bar doctrine. ${ }^{43}$ First, if the seceding group took collective formal action in the name of the union, such as a vote to disaffiliate taken at a local union meeting, the Board could find that there was a "doubt as to the identity" of the bargaining agent creating sufficient confusion to require an election. ${ }^{44}$ Second, if there was no formal collective action but such wholesale desertion by the members that the union had ceased to function, the Board could find the union "defunct" and permit the employees to choose a new representative. ${ }^{45}$ Both of these exceptions were based on the expressed premise that the contract would not be a bar if it did not in fact promote stability in the bargaining relationship. ${ }^{46}$

With the CIO ouster of left wing unions the pattern of a double standard emerged. Although the Board echoed the same verbal formulae, ${ }^{47}$ petitions for elections filed by groups seceding from the left wing unions were granted almost without exception. ${ }^{48}$ During the same period, groups which seceded from other unions were blocked by strict application of the contract bar doctrine. ${ }^{49}$ In 1952 , as the flood of cases arising out of the CIO schism diminished, the Board rationalized its past leniency in these cases by distinguishing them as involving "a basic intra-union conflict over policy and management ... such that no salutary stabilizing purpose could have been served by

43. For an analysis of the cases prior to 1950, and digests of over 70 of the significant cases, see Samoff \& Summers, Disaffiliation, 1 Lab. L.J. 585 (1950).

44. See, e.g., Sun Shipbuilding and Dry Dock Co., 86 N.L.R.B. 20 (1949); Carson Pirie Scott Co., 69 N.L.R.B. 935 (1946).

45. See, e.g., Container Corp. of America, 61 N.L.R.B. 823 (1945).

46. The "doubt of identity" exception was applied with such flexibility and whimsical unpredictability as to defeat even the best efforts to discern any intelligible pattern based on the size of the najority vote to secede, the number of officers seceding, the continued effectiveness of the remnant, or the aid given by an outside union in encouraging the secession.

47. See, e.g., Boston Mach. Works Co., 89 N.L.R.B. 59 (1950); 15 NLRB AvN. REP. 63-67 (1950).

48. "Throughout this period (1950-2) the Board, although giving lip service to the contract bar principle had converted the contract bar into a sieve." Isaacson, The Local and the International, N.Y.U. 5TH ANN. Conf. ON LABOR 413, 430 (1952). This is hinted in the Board's Fifteenth Annual Report. See 15 NLRB AnN. Rep. 64 \& n.31 (1950).

49. See Harris Prod. Co., 96 N.L.R.B. 812 (1951); RCA Serv. Co., 94 N.L.R.B. 1122 (1951); Diagraph-Bradley Indus. Inc., 91 N.L.R.B., 605 (1950); Louisville Ry., 90 N.L.R.B. 678 (1950). 
applying contract bar rules." ${ }^{50}$ At the same time, the Board confessed its laxness and pledged itself to greater sternness. ${ }^{51}$

The left wing union cases, however, continued to tempt the Board, and in $A$. C. Lawrence Leather $C 0 .^{52}$ a special opening was made in the contract bar doctrine for these cases. Where "a local group disaffiliates from a union expelled by its parent for reasons related to the expulsion," the Board will direct an immediate election notwithstanding the existence of a contract. ${ }^{53}$ Through this gate, groups seceding from the ousted internationals paraded freely to elections, while other seceding groups struggled to surmount the contract bar.

The ambivalent quality of the Board's rules is suggested by two cases decided within a year of each other. In Youngstown Steel Door Co. ${ }^{54}$ members of a local of District 50 of the UMW became dissatisfied because they felt that the non-complying status of the union prevented it from protecting their interests. They voted unanimously to secede and join the International Association of Machinists. All of the officers of the old local became the officers of the new local and practically all revoked their old check-off authorizations. The UMW had no visible local organization other than an administrator sent in by the international. The Board refused to order an election. The international, it declared, "has not relinquished its rights under the contract" and since it "remains able and willing to administer the contract and as the employer is willing to negotiate with the Intervenor pursuant

50. Saginaw Furniture Shops Inc., 97 N.L.R.B. 1488, 1491-92 (1952).

51. "In recent decisions, the Board has indicated that henceforth it will not permit the schism doctrine to become an unqualified exception to its contract bar doctrine." Hardy Mfg. Co., 98 N.L.R.B. 811 (1952). The avowed change in policy is revealed by contrasting the Board's statements in its 1950 annual report and its 1952 annual report. Compare 15 NLRB Ann. Rep. 63-67 (1950), with 17 NLRB Ann. Rep. 47-48 (1952).

52. 108 N.L.R.B. 546 (1954).

53. $I d$. at 549 . In the cases prior to 1950 there is no suggestion that expulsion from a federation or a "basic intraunion dispute" was a relevant factor, much less a prerequisite for there being a doubt as to identity. The cases are, in fact, to the contrary. See Samoff \& Summers, supra note 43.

The motivation of at least one member of the Board, Member Rodgers, is made clear in Lawrence Leatber. There the intervenor had not filed non-communist affidavits, the parent union had been expelled from the CIO for communist domination, and union president Ben Gold had been convicted for filing a false non-communist affidavit. Member Rodgers would deny such a union the benefit of the contract bar on the grounds of "broad public policy." See also his concurrences in International Harvester Co., 108 N.L.R.B. 600 (1954), involving the UE, and New Jersey Zinc Co., 108 N.L.R.B. 1663 (1954), involving the Mine Mill and Smelter Workers.

54. 116 N.L.R.B. 986 (1956). 
to the contract there is no warrant for setting aside the contract on the grounds of schism." 55

Contrast with this General Electric Co ${ }^{56}$ where the Board did order an election. The UE and IUE had engaged in a constant battle for control of the local since 1950, and in 1956 the UE won a Board election. At a rump meeting presided over by the local president and attended by less than a fifth of the employees, dissatisfaction was expressed with the handling of grievances and the "Communist taint" of the UE, and disaffiliation was voted. Most of the officers remained loyal to the $\mathrm{UE}$ and it continued to function. At the time of the Board hearing it had a check-off authorization from over half of the employees. The Board found that the secession was for reasons related to the expulsion of UE seven years before "and creates such confusion that the existing contract no longer stabilizes industrial relations." The double standard is self-evident. ${ }^{58}$ For the UMW the test is "defunctness" but for the UE the test is "doubt of identity," even though the secession from the UMW, as much as that from the UE, roots back to the reason which caused disaffiliation from the parent federation. ${ }^{59}$

With the first BCW cases, the Board began to restudy its schism rules. Not surprisingly, the newly stated rules in Hershey Chocolate Corp. ${ }^{60}$ hold wide the door to an election for locals seceding from the corrupt internationals which have been expelled from the AFL-CIO. ${ }^{61}$

55. Id. at 989 .

56. 118 N.L.R.B. 637 (1957).

57. Id. at 640-41.

58. Compare Universal Moulded Prods. Corp., 118 N.L.R.B. 1277 (1957); and West Virginia Pulp \& Paper Co., 118 N.L.R.B. 1595 (1957), in which elections were denied, with Westinghouse Elec. Corp., 116 N.L.R.B. 1642 (1956), and Globe Forge Inc., 115 N.L.R.B. 862 (1956), in which elections were granted. The Board has two sets of "boiler plate" reasons, one set for denying and the other set for granting the election. In these cases either set is equally applicable to the facts, for there is not defunctness but there is confusion. The "boiler plate" selected depends on whether the secession is from an expelled international.

59. In 1947, at the time of the passage of Taft-Hartley, John L. Lewis was a vice president of the AFL. He refused to file a non-communist affidavit under section 9 (h) of the act, and this barred all of the federal locals from recourse to Board procedures. To avoid this, the AFL Convention of 1947 amended the constitution to eliminate the thirteen vice presidents. Angered at this, Lewis disaffiliated and has continued his refusal to comply with the filing requirements. See Alinsky, John L. LEWIS 338 (1952).

60. 2 Lab. Rel. Rep. (42 L.R.R.M.) 1460 ( NLRB Sept. 18, 1952).

61. The principal limitations are that the vote to secede be taken at an "open meeting" called after "due notice to the members in the unit," and that such action 
At the same time, locals seceding from other internationals may find the door locked. Elections will be granted only where there is a "basic intraunion conflict" and this is narrowly defined as a "conflict over policy at the highest level of an international union . . . or within a federation, which results in a disruption of existing intraunion relationships." ${ }^{62}$ Secession is not enough-there must be a schism in the top ranks of the union hierarchy. The test is not what happens in the local, but what happens to the international. Other than for a split such as occurred in the CIO Textile Workers in 1952, there must be either a disaffiliation or expulsion from the federation.

Hersbey Chocolate, like the Board's opinions in the past, solemnly reaffirms the basic consideration "that the existing contract can no longer serve to promote industrial stability, and that direction of the election would be in the interests of achieving industrial stability." 63 The rules, however, like the Board's past decisions, create misgivings, for they seem remotely linked to this basic consideration.

The restrictive definition of "basic intraunion conflict" twists and mutilates the underlying premises by requiring a conflict "at the highest level of an international union ... or a federation." Secession by a local can create confusion and cause such disruption that an election is necessary to stabilize bargaining relationships, regardless of whether the secession grew out of a conflict in the upper echelons of the international or the federation. Secession of a UMW local, as in Youngstown Steel Door, may confuse and disrupt union-management relations as much as secession of a UE local or a BCW local. The basic consideration is not stability in the international union, but stability in the bargaining unit. ${ }^{64}$

Requiring that the secession be "within a reasonable period of time" emphasizes the remoteness of the Board's rules from its professed premises. If a UE local secedes to join the IUE, the existing contract would not promote industrial stability any more in 1956 than in 1950; nor

be taken "within a reasonable period of time" after the intraunion conflict occurs. Whether the secession must be coexistent with the unit is unsettled. Id. at 1464 .

62. $I d$. at 1463 .

63. $l d$. at 1462 .

64. See Krislov, Raiding Among the "Legitimate" Unions, 8 Ind. \& Lab. ReL. Rev. 19 (1954). In 1951 and 1952, there were 1,246 representation petitions filed by one "legitimate" union to replace another. In 407 cases, the new union won the election. Id. at n.1. This free movement may be substantially reduced by the AFL-CIO merger and its No-Raiding Pact. See Aaron, Inter-union Representation Disputes and the NLRB, 36 Texas L. Rev. 846 (1958). 
will secession of a BCW local be any less disruptive in 1960 than in 1958. The impact on the employer, the employees, and the bargaining relationship will be the same regardless of when the secession occurs.

The Board, like the courts, has in the past tailored its schism rules to fit the current fashions. In Hershey Chocolate, it has designed new rules so closely cut that they seem to fit the present needs of the AFLCIO better than the Board's own basic premises.

\section{Lines of Inquiry and Projected Answers}

Strangely missing in both court and Board decisions is any serious wrestling with the difficult problems which secession of a local union creates in the collective bargaining relationship. The courts juggle contract theories or search for dirty hands, quite oblivious to the very reason for a union's existence. The Board beams with glowing generalities of "industrial stability," but aside from asserting bald conclusions, evidences no careful study from which it might determine what rules would best enable the employees and the employer to secure the full benefits of collective bargaining.

Designing legal rules to meet these needs is not easy, for it requires a careful factual analysis of secession situations and their impact on the bargaining relationship. Only by determining how the parties in fact behave in these situations, can we sensibly speculate how the law might best be framed to achieve its objectives. Such a study, to my knowledge, has not been made. However, it may be valuable to suggest certain lines of inquiry and to project answers based on limited evidence. The tentative conclusions can then serve as hypotheses to be tested by further study of the facts.

Secession seems to have three distinctive features. First, instead of gradual erosion of the local by individuals withdrawing and joining another local, secession is a concerted action taken by a major block of the members to transfer as a unit to another union. Second, secession is signalled by some formal collective action, normally a vote by members of the local at a meeting. The action is taken in the name of the local and purports to sever the local as an entity from its parent. ${ }^{65}$ The effectiveness of the action is normally challenged by a loyal remnant of the international. Third, the claims made by the secessionists

65. In some instances, the old local attempts to transfer its assets to the officers or some other persons, votes to disband and then forms a new local. This is done only as a legal maneuver to attempt to save the local's assets. See, e.g., Local 2618, of The Plywood \& Veneer Workers v. Taylor, 197 Wash. 515, 85 P.2d 1116 (1938). 
and the loyal remnant do not conflict over who has the majority in the bargaining unit, but who is the local union. The whole character of the formal action gives the secessionist group a colorable claim of legitimacy in the eyes of its adherents. There are thus created two warring groups, each claiming to be the sole rightful representative. The doubt as to identity may be legally spurious, but it is psychologically real. In addition to these distinctive features there appear to be certain rather common characteristics. The seceding group almost always includes the officers of the local union. ${ }^{66}$ The reasons for secession may vary widely or be multiple, but dissatisfaction with the terms of a particular collective contract is almost never a major motivating force.

The second and perhaps most important line of inquiry is, what is the practical impact of secession on the collective bargaining relationship? Limited evidence indicates that the act of secession triggers immediate turmoil with uncertainty as to who is the authorized representative to settle grievances and administer the contract. The employer is confronted by conflicting claims; if he deals with one he is execrated by the other. Members of one group may refuse to process grievances through the other, and settlements made by one may be repudiated by the other. The grievance procedure becomes a battleground instead of a conference table. The whole purpose of collective bargaining as a continuing process to work out the problems of industrial relations is frustrated, and the peace for which the employer bargained is lost. ${ }^{67}$

If this is the effect of secession, reestablishing bargaining requires a definitive determination of the rightful representative. The effectiveness of that decision, however, may depend on how it is made. Board

66. The normal pattern is for the local officers to lead the secession and automatically become the officers of the newly affiliated local. See, e.g., West Virginia Pulp \& Paper Co., 118 N.L.R.B. 1595 (1957); Universal Moulded Prods. Corp., 118 N.L.R.B. 1277 (1957); Wayne Pump Co., 117 N.L.R.B. 25 (1957); Westinghouse Elec. Corp., 116 N.L.R.B. 1642 (1956); Youngstown Steel Door Co., 116 N.L.R.B. 986 (1956). For an unusual case where only one officer sided with the secessionists, see General Elec. Co., 118 N.L.R.B. 637 (1957).

67. The employer may, of course, prefer to deal with the remnant even though it is but a shadow embodied in the international representative. See, e.g., West Virginia Pulp \& Paper Co., supra note 66; Youngstown Steel Door Co., supra note 66. On the other hand, he may wish to keep the factions fighting between themselves. This does not mean that genuine collective bargaining will thereby be established but may only mean that the employer seeks to use the turmoil to avoid or frustrate bargaining. 
refusal to hold an election when the bulk of the union members have seceded is not likely to bring bargaining stability. The remnant, clothed with official status, may go through the motions of settling grievances, but the underlying dissatisfactions will only be magnified by resentment, and may develop unofficial dealing with the seceding group. Not only is the grievance procedure gutted, but the contract becomes a shell. The seceding local feels no obligation to abide by it, and the remnant has no practical ability to enforce it. An election may not put the matter wholly at rest, particularly if the two factions are relatively equal, but it can help clear the air and gain for the winning group the acquiescence which comes with majority rule.

If we accept these hypotheses as to the distinctive features of secession and the impact of secession on collective bargaining, what tentative conclusions are suggested as to the rules concerning representation elections? First, the Board should order an election in all cases where secession has in fact created substantial confusion among the employees over who is the rightful representative. In determining this factual issue, one of the critical considerations should be the secession procedure used, for it is this which gives the seceding group the color of legitimacy and creates confusion. ${ }^{68}$ Second, the immediate needs would be better served by limiting the choice on the ballot to the two contending factions. To allow intervention by other unions which seek to sever segments of the unit reopens the whole appropriate unit problem and may lead to lengthy representation proceedings. Resolution of the disruptive conflict is delayed while matters wholly unrelated are litigated. ${ }^{69}$

The Board has rejected rules which would apply equally to all secession cases on the grounds that they "could be utilized to facilitate a raid or to permit a dissident group to repudiate the bargain made by the existing representative." 70 Unfortunately, the Board has presented

68. The Board's requirement in Hersbey Chocolate, that secession be voted at an open meeting called with due notice of its purpose, not only provides a workable standard for formal collective action but is directly related to the weight which the employees will give that action as a legitimate decision of the local union.

69. The Board's position in Hershey Chocolate seems to assume that the bargaining relationship is beyond repair and that the practical solution is to treat it as at an end and make a clean start with a full representation proceeding. However, there is no evidence that such total disruption is necessary in schism cases. On the contrary, the seceding local usually seems prepared to continue the relationship without interruption.

70. Hershey Chocolate Corp., 2 Lab. Rel. Rep. (42 L.R.R.M.) 1460, 1463 (NLRB Sept. 18, 1958). 
no factual evidence that these dangers are substantial. Inducing secession would appear to be the most difficult form of raiding, for it requires concerted repudiation of the international, usually possible only with the aid of officers for whom the ties of loyalty to the international are strongest. Obtaining an earlier election would scarcely be worth the raiding union's extra effort. ${ }^{71}$ The fear that secession will be used to escape the contract seems to be little more than bogey building without factual foundation. Furthermore, this danger could be eliminated by requiring the seceding group to assume the contract.

This leads to one of the most difficult and unilluminated areas of inquiry. If the Board orders an election, what rules concerning the continued effectiveness of the contract will best serve to re-establish bargaining stability? If the remnant international segment wins the election, the contract will probably continue uninterrupted. If the seceding segment wins, it becomes the exclusive bargaining agent, and the employer can give no recognition to the remnant group. The question is whether the secessionist group, if it wins, should be bound as successors to the contract or whether it should be free to bargain afresh.

Secession is almost never rooted in dissatisfaction with the contract, and the election is not ordered to permit escape from the contract. However, if the seceding group is not bound, the continuation of the contract depends on the outcome of the election, and the seceding group may seize this as an argument for votes. Thus, an issue which is spurious to the reasons for the election, and which stability of bargaining dictates should be excluded, is injected into the situation. From the employer's viewpoint he has a strong claim that the contract be continued, and that he obtain the stability of labor costs and employment conditions for which he has bargained. He should not be deprived of his bargain because of a family fight within the union. ${ }^{72}$

These considerations point in the direction of treating the seceding group as successor to the contract. This is the rule of the National

71. Rival unions frequently stand ready to catch the severed local, and may attempt to help break it loose, but there is serious doubt how much influence they can exert. The very intervention of outsiders may fire loyalities and block secession.

72. If the Board allows intervention and a craft unit is severed, there may be theoretical problems whether the union or employer is still bound by the truncated agreement. Apparently, this has created no practical problems. 
Mediation Board ${ }^{73}$ and was the early rule of the NLRB. ${ }^{74}$ However, after several intervening years of coyly refusing to answer the question, ${ }^{75}$ the Board now apparently has rejected the rule. ${ }^{76}$ Unfortunately the Board gives no reason for its position, nor have other writings made explicit what difficulties would be created. ${ }^{77}$ The fact that normally the seceding group accepts and continues the contract suggests that many of the supposed difficulties can be easily overcome. ${ }^{78}$ It is easy to conjure obstacles and throw up one's hands. ${ }^{79}$ More fruitful, however, would be a careful study of actual secession situations to determine the general applicability of the solutions developed where substitution is in fact accomplished..$^{80}$

The final area of injury concerns what disposition of the local's assets will best achieve the purposes of collective bargaining. Collective bargaining requires an effective union, and to be effective the union must have financial resources with which to negotiate and ad-

73. See 1 NMB Ann. Rep. 23 (1935).

74. See Register \& Tribune Co., 60 N.L.R.B. 360 (1945); Harbison-Walker Refractories Co., 43 N.L.R.B. 1349 (1940); New England Transp. Co., 1 N.L.R.B. 130, 138 (1936).

75. See, e.g., Boston Mach. Works Co., 89 N.L.R.B. 59, 61 (1950).

76. See Hershey Chocolate Corp., 2 LaB. Rel. ReP. (42 L.R.R.M.) 1460 (NLRB Sept. 18, 1958).

77. See Isaacson, The Local and the International, N.Y.U. 5TH ANN. Conf. on LABor 413, 433-41 (1952); Mayer, Interunion and Intraurnion Relations, 9 LAB. L.J. 105, 118 (1958); Note, 19 Cinn. L. Rev. 379, 386-88 (1950); Note, 63 Harv. L. Rev. 1413, 1423-26 (1950); Note, 66 Yale L.J. 223, 240-42 (1956).

78. See, e.g., Fitzgerald v. Haynes, 146 F. Supp. 735 (M.D. Pa. 1956); Retail Clerks Int'l Ass'n v. Neifeld, 73 Pa. D. \& C. 60 (C.P. 1950) (26 L.R.R.M. 2365); Local 13013, District 50, UMW v. Cikra, 86 Ohio App. 41, 90 N.E.2d 154 (1949); Globe Forge Inc., 115 N.L.R.B. 862 (1956); Muskin Mfg. Co., 114 N.L.R.B. 1307 (1955); Standard Conveyor Co., 114 N.L.R.B. 1447 (1955). See also Memorandum on Behalf of the AFL-CIO, p. 21, Hershey Chocolate Corp., 2 LaB. ReL. Rep. (42 L.R.R.M.) 1640 (NLRB Sept. 18, 1958) which states: "It is our observation that in most schism situations the prevailing union is willing and even anxious to assume the existing contract." The AFL-CIO, however, opposed requiring the seceding group to assume the contract on the grounds that the contract may be substandard because of collusion with the employer.

79. There is no insuperable obstacle to substituting the seceding local, and even its new parent international, into the representation, check-off, union shop, and nostrike clauses. Perhaps the greatest difficulties will arise out of the pension and welfare clauses, especially where the international has pooled funds. See Cohn, The International and the Local Union, N.Y.U. 11TH ANn. Conf. on LABOR 7 (1958). These problems exist, however, regardless of whether there is substitution.

80. For a discussion of whether the Board or the state courts are the proper forum for working out this problem, see Isaacson, supra note 77; 66 YALE L.J. 223, 241-42 (1956). 
minister collective agreements and to carry on other activities. ${ }^{81}$ If the seceding group wins the election, it is then charged with representing the employees and has immediate need of funds to discharge this responsibility, where the remnant attempts to cling to funds accumulated for purposes now gone. To award the assets to the seceding local under such circumstances will help give the employees effective representation and re-establish meaningful collective bargaining. ${ }^{82}$

This reasoning gains force when the secession is either unanimous or nearly so, as seems to be the case in most situations. However, if the split is more nearly even, ${ }^{83}$ it is hard to say that the loyal remnant should be stripped financially. There are values in its preservation as an effective challenger which can keep the employees' freedom of choice real. A solution which could serve these two intersecting needs would be to divide the funds if the seceding group won the representation election, awarding to each group a proportionate share based on its number of members. ${ }^{84}$

These hypotheses as to how the law should dispose of the assets assume that the assets are a significant practical factor in secession situations. ${ }^{85}$ No studies have been made to determine whether this is true. Current dues, supplemented by aid from the international, may

81. This practical need was recognized in Kralstein v. Sorchinski, 41 L.R.R.M. 2528, 2530 (N.J. Super. 1958): "Someone has got to service this Local Union and take care of the dues and grievances, transfers, the layoffs, the retirements, all the unnumberable $[s i c]$ questions that arise in connection with the operation of a large organization such as this Local Union. It costs money to do that."

82. A roughly equivalent solution was devised in Huntsman v. McGovern, 91 N.E.2d 717 (Ohio C.P. 1949). The court ordered election of temporary officers to hold the union funds and administer the contract pending an NLRB election. If the seceding group won the representation election, it would be allowed to take with it the local assets and the contract. In General Elec. Co. v. Emspak, 94 F. Supp. 601 (S.D.N.Y. 1950), the parties apparently stipulated that the check-off funds should go to the one winning the NLRB election.

83. See, e.g., Seslar v. Union Local 901, 186 F.2d 403 (7th Cir. 1951); Westinghouse Elec. Corp., 116 N.L.R.B. 1642 (1956).

84. Funds which are held by the union to provide personal benefits to members, such as insurance, and pension and welfare funds, involve different considerations than those held for bargaining or other continuing activities of the union. The individual member has a special purpose interest in such benefit funds. To deprive him of that interest because he shifts his allegiance to another union would seriously inhibit his freedom of choice, which is central to collective bargaining. This likewise suggests a division of the funds between the two groups.

85. The dollar value of the assets may be large. Nadworny v. Emery, 25 L.R.R.M. 2594 (Mass. Super. Ct. 1950) (\$300,000); Fitzgerald v. Abramson, 89 F. Supp. 504 (S.D.N.Y. 1950) $(\$ 195,000)$. However, the amount per capita may be small and the fate of the assets may play little part in the members' decision to secede. 
well be adequate for bargaining needs. Holding the assets may be of more psychological than financial importance, and once the secession is fully accomplished the outcome of the lawsuit may be largely irrelevant. ${ }^{86}$ The fact that so many of the suits for assets are never pursued beyond the trial court creates a suspicion that the assets may in fact be of minor practical importance. ${ }^{87}$

\section{Conclusion}

Protecting and stabilizing collective bargaining is not the sole value to be considered in developing rules to govern secession cases. The value of limiting legal interference in internal union affairs, the value of restricting courts and other agencies to tasks for which they are suited, the value of preserving individual free choice within the collective system-these and other values must be weighed and may at times control. ${ }^{88}$ However, none of these values can be protected without a more complete knowledge of the secession phenomenon.

The attempt to chart the most obvious lines of inquiry and to sketch the simplest framework of rules graphically reveals the large number of critical facts which must be assumed. Neither the Board nor the courts have sought to discover what in fact happens in a secession situation nor to determine how the parties respond to the existing legal rules. The courts may be excused, for the law of voluntary associations has diverted their attention from the union's unique role in collective bargaining, and the courts are procedurally handicapped in studying the functioning of institutions. The Board, however, can not be so easily excused, for it professes to seek bargaining stability, and has means available to make an objective factual study of the impact of its rules on the institution for which it is primarily responsible.

86. An explicit legal rule that the seceding group could not take the assets might deter the local officers from considering secession. However, physical possession of the assets seems to give a sense of power and confidence that dissipates doubts created by abstract legal rules. Their confidence may not be misplaced. There is some reason to suspect that the group in possession of the funds often keeps possession long enough to use them in carrying on the union.

87. A legal rule permitting the seceding group to take all or a substantial portion of the local assets might encourage raiding unions to use the secession device. With the union treasury as a prize, they might find it worthwhile to try this more difficult method. This, however, is impossible to predict without knowing more of the present significance of funds in secession.

88. For example, if right to the local assets plays no significant part in secession cases, then it may be better to select some rule which will simplify the court's role, avoid judicial involvement in union rules or policies, and protect the individual members. These values might point to a mechanical division of the assets between the factions according to their membership. 